\title{
Theory of Capital, Investment and Exchange Rate: A New Developmentalist Equation
}

\author{
Cristina Helena Pinto de Mello \\ ESPM-SP, São Paulo, Brazil
}

\begin{abstract}
The article deals with the relationship between the decision to invest and the exchange rate. The literature relates investment at interest rate. An increase in the interest rate would reduce the investment expenditure. Jorgenson's equation uses the flexible accelerator model, taxation, and the cost of capital to explain and predict the amount of investment in machinery and equipment. The relationship between the exchange rate and the investment appears in the literature as a direct relation. An appreciated exchange rate allows the importation of cheaper machinery and equipment and increases productive investments. This paper proposes a modified equation in which the appreciated exchange rate inhibits productive investments by reducing the expectation of profit, either because the domestic market becomes more competitive or because exports decrease. It still incorporates in the model of Jorgenson the idea that the unit cost of labor is the relevant variable to explain the choice of investing, assuming a function of production of fixed coefficients.
\end{abstract}

Keywords: investment, exchange rate, economic development, decision, expectation, profit

\section{Introduction}

Relating investment decisions on profit expectations in uncertain environments and the interest rate was one of the contributions of Keynes to the economic debate. Thus, he attributed an important role in the monetary policy in the definition and choice of resources allocation. The current debate on the non-neutrality of money has summarized up to a discussion between short and long term, rational or adaptive expectations (authors). There was little discussion about the neutrality of money in a complex global monetary architecture. The lack of coordination of monetary policy, or even the impossibility to affect global prices for small economies, changes the resources allocation. This paper seeks to relate the exchange rate to investment decisions, proposing an equation to estimate the impact of exchange rate changes and their level in the productive choices, thus understanding that coordination between monetary policies is not neutral.

In the definition of Keynes (1936), the marginal efficiency of capital is "the discount rate that would make the present value of the annuities stream of the expected rents of this capital, throughout its existence, exactly equal to its offer price" and decision to invest occurs up to the point where the marginal efficiency of capital is equal to the interest rate. Tobin treated this equality as a reason, arguing that the decision to invest occurs when the market value of the company is greater than the cost of replacement of an incremental unit of capital. On its

Cristina Helena Pinto de Mello, Ph.D. in economics at FGV-SP, deputy coordinator of the Professional Master's Program in Consumer Behavior at ESPM, professor of Economics at the Catholic University of São Paulo (SP), São Paulo, Brazil.

Correspondence concerning this article should be addressed to Cristina Helena Pinto de Mello, Rua Dr. Alvaro Alvim, 123, 04018-010, São Paulo, Brazil. 
turn, in Bresser-Pereira (1991), companies require a profit fee higher than the interest rate, so that this variable becomes less relevant in determining investments. According to him shifts of the liquidity preference curve would be more important. More recently, he suggests that the expected profit rate is affected by the exchange rate.

For Bresser-Pereira (2012), due to the tendency to cyclical and chronic overvaluation (on long-term) of the existing exchange rate in developing countries, an exchange rate policy that neutralizes this trend and makes the exchange rate competitive can stimulate the carrying out of investments, to the extent that it is the exchange rate that assures the companies of the country that use technology in the state of the art worldwide access to existing demand both external and internal. By prioritizing the profit expectation to make productive investments, Bresser suggests that there is a positive relation between the exchange rate and the choice of capital goods acquisition.

Although relevant, the specification of an investment function in Brazil that considers capital flows in open economies has not been specified in the literature. The present article aims to propose an expanded version of the theory of flexible accelerator of Dale Jorgenson that incorporates capital flows and the exchange rate in the equation; either because the capital structure can be built on carry trade operations, or because the expected profitability depends on the exchange rate. In short, either because of the conditions for funding, or by shifting the marginal effectiveness of capital, this paper proposes an equation that relates the productive investments to exchange rate.

\section{The Exchange Rate and the Investments}

Developing countries often need to import equipment, either because they do not produce enough internally, or because of available technology. The import of this equipment is compatible with an external constraint. The consequences are similar to the concept of credit rationing. There are limits to finance the import of capital.

Except for the new developmentalist contribution, the relation between the exchange rate and the decision to invest is often inversely related. As mentioned, the effect of the exchange rate on the import of machinery and equipment is taken into consideration and thus an increase in the exchange rate would inhibit productive investments. Although the relation between GDP fluctuation and thus, aggregate demand, and the variation in the stock of desired capital is enshrined in the models and arguments of the accelerator effect, little is said about a possible positive relation between the exchange rate, aggregate demand, and the productive investments.

The new developmentalist thesis argues that the exchange rate is inversely related to the gross fixed capital formation, especially in the case of Dutch disease. In these circumstances, chronic and structural appreciation of the exchange rate is a limiting factor to productive investment due to depressing the expectation of profit.

The discussion about the relevance of exchange rate often appears in the literature associated with impacts on foreign trade, capital flows, and the behavior of inflation. Possible allocative impacts and, in particular, the relation to the decision to productive investment are barely discussed. When it's found an association between investment and exchange rate, this relation is ambiguous.

According to Servén and Solimano (1993), the impact of a depreciation of the real rate exchange on the relative prices of capital goods has a major effect on the investment profitability. According to the authors, capital goods are composed of a combination of domestic components (construction and infrastructure) and foreign components (machinery and equipment). An increase in the exchange rate makes imported goods relatively more expensive, discouraging the import of 
capital goods while a reduction in the exchange rate stimulates imports of capital. Thus, it is expected that the relation between investment and exchange will be negative. (Alves, 2007, p. 3)

The new developmentalist thesis rejects this statement and argues that the exchange rate is inversely related to the gross fixed capital formation, because the exchange rate tends to be appreciated in the long run because of the Dutch disease (which exists in most developing countries) and the three usual policies that appreciate the exchange rate: the growth policy with deficit in the current account, the high interest rates policy and an exchange rate anchoring policy to control inflation. Soon after, however, this depreciation that assumes once and for all makes industrial companies in the country becomes competitive and increases its profit expectations and so they begin to invest and promote growth.

The proposition of new-developmental theory is therefore counterintuitive, in the sense that states that the relation between investment and the exchange rate is positive.

A reduction in the exchange rate foments an increase in the relative price of non-tradable goods in favor of prices of tradable goods. Thus, there is an increase in the expected profitability in non-tradable goods sectors, either because prices become relatively higher, or because the importation of machinery and equipment becomes cheaper. The analogous and reverse growth in exchange rate reduces the price of non-tradable goods and raises the price of tradable goods. In this second case, the expected profits for the tradable goods sectors rise so as to stimulate investments in this sector and change the allocation of resources. Another issue that arises is the effect of prices on the capital structure of companies. Growing prices allow both to raise the profit retention and the financing with equity instead of using third-party resources. As a significant portion of private savings is formed by companies, rising in prices tends to stimulate an increase in savings. As a change in the exchange rate changes allocative choice between sectors, it is assumed that its effect on the volume of investment is negligible. But if the allocative change redirects productive resources for the service sector, especially the segment of less sophisticated production, then can be expected a reduction in the volume of inversions in fixed capital, compromising the growth rate.

There is still to be considered the effect of financial flows on the capital market. A positive capital flow can both promote the exchange appreciation as increase the demand price of the investments, measured by the trading value of multiple places. Empirical evidences of a positive relation between the exchange rate and the stock price can be found in Carvalho and Vieira's work (2015). Thus, another way to explain deindustrialization is associated with a change in the Tobin's q discouraging investments in the sectors which are traded in exchange stock, where it's possible to compare the purchase price of a new investment with the price of a good existing investment.

Maintaining the exchange rate at the desired level to promote economic growth not only causes a change in the allocation of resources, but also has desirable monetary impacts for the financing of investments in the event that these are elastic with respect to the interest rate. This is because an increase in the exchange rate is usually accompanied by a monetary expansion and, consequently, a reduction in interest rates. But for this work, it is supposed that firms prefer to finance the capital expansion with internal resources and not with third-party capital.

A chronic exchange rate appreciation in the long run, promotes the reduction of profit margins of companies in the country, which are no longer able to export as well as lose the local market in favor of imports. Bresser calls this latter relation "the problem of access". The combination of an expansionary policy with 
appreciated exchange rate generates demand for imported products, but local companies have "access" to this demand due to the exchange rate.

For the purpose of this paper, it is considered that the exchange rate has important allocative effects on orienting investments and hiring in the tradable and non-tradable sectors. And, even though the uncertainty and risk inherent in the choice of investment in fixed capital are related to innumerable factors such as political risk, inflation, discretionary policies, among others, it will be considered for the purpose of this work the exchange rate - as measured by the standard deviation of the rate of commercial exchange, as a measure of risk and uncertainty relevant to the choice of investing in fixed assets, whose characteristic is the irreversibility.

For Bresser-Pereira, the volatility of the exchange rate is long term, and is expressed in the tendency to the cyclical and chronic overvaluation of the exchange rate. In this case, the level of the exchange rate- the long-term rate, which is appreciated - weighs on the decision to invest, either for guiding the allocation of resources into sectors of tradable and non-tradable goods, either for affecting the expectation of profits by indication of the possibility of access to domestic and international markets, or by reducing or increasing the purchase price of equipment when imported. And still, for affecting the average comparative cost of labor and the cost of financing new investments.

Ideally, it should be researched which variation, or amplitude, is understood as a risk that might cancel investment decisions and what variations are considered normal and, therefore, have no effect on investment decisions in fixed capital. Thus, it would be possible to incorporate the risk associated with currency fluctuations as a dummy, multiplying the investment equation. In this way, in view of high volatility, the variable becomes zero, nullifying any positive effects on the possible choice of investments. However, in the case of a low variability, the variable assumes a unit value in order to nullify its effect on the choice of investment. In this case, weigh heavily on the decision to invest the level of the exchange rate, either because it guides the allocation of resources in the tradable or non-tradable goods sectors, either because affects the profits expectation which indicates the possibility of access to external and internal market, or by reducing or increasing the purchase price of imported equipment. Moreover, by affecting the average comparative cost of labor and the cost of financing, although the literature identifies that companies are chiefly financed with equity, it also identifies the credit constraint as a significant limitation in developing countries.

Rama (1993) summarizes the literature on investment decision in industrialized countries relating them to two basic arguments: the accelerator effect and the relative prices of capital and labor; therefore, the expected profitability. On the other hand the literature on the decision to invest in developing countries considers other four factors as relevant in determining the volume of productive investment: credit rationing, exchange restriction, shortage of infrastructure and economic instability.

In this way, the paper intends to specify an equation that contemplates the relation or the possible relations between the exchange rate and productive investment.

\section{Investment Models}

There are some main models of investment: the accelerator model, Tobin's flexible accelerator.

The capital stock is both a function of the level of activity (accelerator model), as a function of cost of capital, which may be represented by the equation:

$$
\mathrm{K}=\mathrm{f}(\mathrm{Y}, \mathrm{Ck})
$$


The Jorgenson's function "specifies the goal function of a firm in terms of maximizing the present value of receipts over disbursements with wage current costs and investment spending".

It implies an optimal structure of capital determined by the level of activity and the cost of purchasing machinery and equipment that can be described as follows:

$$
\mathrm{K}_{\mathrm{t}}^{*}=\mathrm{p}_{\mathrm{t}} \mathrm{Y}_{\mathrm{t}} / \mathrm{c}_{\mathrm{t}}
$$

The conditioned optimization function can be specified as follows:

$$
\mathrm{I}_{\mathrm{t}}=\beta\left(\alpha \mathrm{y}^{\mathrm{t}} \mathrm{c}_{\mathrm{t}}^{-1}-\mathrm{K}_{\mathrm{t}-1}\right)+\delta \mathrm{K}_{\mathrm{t}-1}
$$

where, $I_{t}$ stands for productive investment, $\beta$ for an adjustment coefficient, which measures the time lag between changes in the stock of desired capital and the decision to invest, $\mathrm{y}^{\mathrm{t}}$ is the product, $\mathrm{c}_{\mathrm{t}}{ }^{-1}$ is the capital service costs, capital stock in the previous period and $\delta \mathrm{K}_{\mathrm{t}-1}$ designates the investment of depreciation compensation. Note that the expression $\left(\alpha \mathrm{y}^{\mathrm{t}} \mathrm{c}_{\mathrm{t}}^{-1}\right)$ denotes the stock of desired capital.

It is possible to recognize the importance of the expected returns, affected by short-term costs, as well as interest rates, depreciation rules, and the purchase price of new machinery and equipment.

The cost of the capital service is affected by the price index for capital goods, taxes, rules of deductible depreciation in taxation and the real rate of interest or cost of capital. This relation can be defined by the equation:

$$
\mathrm{c}_{\mathrm{t}}=\mathrm{q}_{\mathrm{t}} / 1-\mathrm{u}_{\mathrm{t}}\left[\left(1-\mathrm{u}_{\mathrm{t}} \mathrm{w}_{\mathrm{t}}\right) \delta+\mathrm{r}_{\mathrm{t}}-\left(\mathrm{q}_{\mathrm{t}}-\mathrm{q}_{\mathrm{t}-1}\right) / \mathrm{q}_{\mathrm{t}}\right.
$$

where, $c_{t}$ is the cost of capital service, $q_{t}$ is the price index for capital goods, $u_{t}$ is the tax rate, $w_{t}$ is the reducing depreciation portion of taxable result, $\delta$ is the depreciation rate, $r_{t}$ is the cost of capital or the real rate of interest.

This model is a reduced form of Jorgenson's model because it will consider only one time lag. The full model considers the full lags or a distributed lag function of the optimal capital stock.

Another determinant the cost of capital is the subsidies and taxation.

Jorgenson's model deals with the optimization problem of a competitive firm, in hypothetical lack of adjustment costs, Cobb-Douglas type production function and constant returns to scale, among others. Jorgenson (1963) comes to the model that follows:

$$
\mathrm{K}=\mathrm{a} \mathrm{Y} \mathrm{Ck}^{*}
$$

where, $\mathrm{Ck}$ indicates the cost of capital uses and reflects the share of capital in the Cobb-Douglas production function.

Likewise the throttle model, this was also modified to take into account the serial correlation of investment, present in the gaps between decision-making and the implemantation of investment, creating a distance between the current and desired capital stocks. The equation for change in the stock of capital was denominated flexible neoclassical model (see Hall \& Jorgenson, 1967):

$$
\mathrm{I}=\lambda\left[(\alpha \mathrm{Y} / \mathrm{Ck})-\mathrm{K}_{\mathrm{t}-1}\right]
$$

where, $0<\lambda<1$ indicates the speed of adjustment of the capital stock.

\footnotetext{
1 Ronci, 1988.
} 
The paper aims to incorporate the exchange rate into the model, since the expected returns are a function of future possibilities for realization of production, which includes the expectation of export and domestic sales. Thus, a currency appreciated affects negatively the return expectations regarding the exportable portion of the production, either in quantum or in monetary values. However, this same appreciated exchange rate has a positive effect on investment in that it shifts production chains, reducing the short-term production costs and the purchase prices of new machinery and equipment.

\section{The Exchange Rate, Investments and the New Developmentalists}

Bresser (2010) argues that the exchange rate that ensures economic development is that one which neutralizes the Dutch disease and corresponds to what he calls industrial balance. In other words, the exchange rate assures the possibility of being competitive to firms with productive sophistication.

This article seeks to explore the idea that when the exchange rate is below the industrial balance, it affects profit expectations and investment of business and leads to deindustrialization. However, the effect of exchange rate appreciation on the expected future return must be greater than the effect of the exchange rate on the cost of capital and on the short-term costs. If the second effect is significantly higher, the exchange rate appreciation will stimulate productive investments.

Myers and Majluf, in 1984, showed that companies are not indifferent to the capital structure, privileging the use of internal funds to finance investment and resorting to indebtedness and the issuance of shares, in this order, only in case of insufficiency of internal resources. (p. 188)

The paper assumes that companies prefer internal funds to finance the investment. However, resorting to external financing resources includes carry trade options.

The hypothesis behind this argument is that there is no global monetary neutrality. Thus, relative prices are affected by coordination, or lack of it, of national monetary policies.

The equation of investments should also consider the relation between the expected returns and the cost of capital or the interest rate. But the free mobility of capital makes the local interest rate become a restriction only to investment of firms without access to the global market. The impact of exchange rate appreciation, therefore, would not be sensed in the short term. Thus, testing time lags can be significant.

The investments function proposed here is:

$$
\mathrm{I}=\mathrm{f}\left(\mathrm{e}_{\mathrm{t}} / \mathrm{e}_{\mathrm{t}+1}, \mathrm{e}_{\mathrm{t}}, \mathrm{ICUTT}, \mathrm{Y}\right)
$$

where, $I$ is productive investment, $e_{t} / e_{t+1}$ is a proxy for the equilibrium interest rate and for the exchange devaluation expectation in period $t$, and $t$ is the exchange rate at time $t$, ICUTT is the comparative index of average work cost and $\mathrm{Y}$, the level of activity.

Moreover, considering the tendency to equalization of interest rates and the equation:

$$
\mathrm{I}_{\mathrm{e}}+\text { risco }=\mathrm{I}_{\text {Dus } \$}=\mathrm{I}_{\mathrm{d}}\left(\mathrm{e}_{\mathrm{t}} / \mathrm{e}_{\mathrm{t}+1}\right)
$$

Besides the interest rate, the relation between the current and future exchange rate also affects the capital structure of local firms and can be an important explanatory factor for private investment behavior.

In the Jorgenson's model (1971) the investment is a result of the need to adjust the company' capital stock to its optimal level. The difference between the optimal capital stock and the actual capital stock can be described by: 


$$
\mathrm{K}_{\mathrm{t}}-\mathrm{K}_{\mathrm{t}-1}=(1-\lambda) *\left(\mathrm{~K}_{\mathrm{t}}^{+}-\mathrm{K}_{\mathrm{t}-1}\right)
$$

where, $K_{t}$ is the capital stock in period $t, K_{t}^{+}$is the desired capital stock in period $t$ and $K_{t}-K_{t-1}$ is the variation of stock of capital corresponding to the volume of investments. When considering investment as an adjustment in the stock of capital in order to optimize it, equipment replacement is disregarded as an investment. As Jorgenson, the replacement investment can be considered as a fixed fraction of the capital stock.

$$
\mathrm{I}_{\mathrm{r}}=\alpha \mathrm{K}_{\mathrm{t}}
$$

where, $I_{r}$ is the replacement investment, $K_{t}$ is the capital stock in period $t$ and $\alpha$ the fraction that may be deduced from a depreciation policy.

Thus, the total investment can be described by the formula:

$$
\begin{gathered}
\mathrm{I}=\alpha \mathrm{K}_{\mathrm{t}}+(1-\lambda) *\left(\mathrm{~K}_{\mathrm{t}}^{+}-\mathrm{K}_{\mathrm{t}-1}\right) \\
\mathrm{K}_{\mathrm{t}}-\mathrm{K}_{\mathrm{t}-1}=(1-\lambda) *\left(\mathrm{~K}_{\mathrm{t}}^{+}-\mathrm{K}_{\mathrm{t}-1}\right)
\end{gathered}
$$

The choice of Jorgenson's model respects the thesis that productive investments are somehow endogenous, in the sense that the optimal capital stock depends on aggregate demand, or product level and the degree of the installed capacity. But the Jorgenson's model is also known as Neoclassical model as it supposes a production function from which the company seeks to maximize profits. Therefore, a change in relative costs of production, including equipment and workers, would promote a change in the optimal capital stock. Thus, the increased cost of machine use would cause a reduction in investments and an increase in the cost of workers would cause an increase in investments. Although the use of a production function is incompatible with the new developmentalist theses, increasing costs of the Labor Unit Cost is understood as a factor affecting the stock of desired capital, but not in the sense employed by Jorgenson. The increase in unit labor cost decreases profit expectations by reducing spending on investment rather than change the resource allocation.

Hence, instead of a Cobb Douglas function, as used by Jorgenson, it will describe a production function based on unit labor costs that can be defined as follows:

$$
\mathrm{CUTr}=\mathrm{Cm} / \mathrm{A}^{2}
$$

where, CUT is the unit cost of labor, Cm the actual average costs of labor per hour worked and A productivity of labor.

Another key difference between the Jorgenson's equation and the New Developmentalist proposal is that for the former, a change in the cost of workers makes it attractive investing in equipment, considering the expected return and the acquisition cost of capital. But, in an open economy, a change in unit labor costs that cannot be offset by a decrease in the cost of machinery and equipment, reduces the profit expectation and therefore discourages productive investment. There are also strong evidences of correlation between the average cost of labor and the exchange rate. Therefore, it is essential to compare the average labor costs in terms of reserve currency.

So, instead of describing the optimal capital stock as a direct function of the level of activity and inversely related to the cost of capital use, the new equation will describe the optimal stock as a direct function of the level of activity and inversely related to the unit cost work.

\footnotetext{
${ }^{2}$ On the unit cost of labor and this formula, see: http://www.bcb.gov.br/htms/relinf/port/2007/12/ri200712b8p.pdf.
} 


$$
\mathrm{K}_{\mathrm{t}}^{+}=\beta \mathrm{Y} / \mathrm{CUTr}
$$

Additionally, the comparison between the CUTr in reserve currency with the unit cost of labor in other countries allows us to think about the allocation of resources in global terms. Hence, if CUTr is reduced in Mexico, profit expectations increase with the possibilities of future sales, which include the global market, and increase the optimal capital stock. Therefore, the comparative index of unit labor cost constitutes a relevant variable for the investment decision.

The new conditional optimization function can be specified as follows:

$$
\mathrm{I}=\beta\left(\alpha \mathrm{Y}_{\mathrm{t}} \operatorname{ICCUTr}_{\mathrm{t}-1}, \mathrm{~K}_{\mathrm{t}-1}\right)+\delta *\left(\mathrm{~K}_{\mathrm{t}-1}\right)
$$

And the equation that describes the cost of capital service would be replaced by:

$$
\mathrm{c}_{\mathrm{t}}=\mathrm{q}_{\mathrm{t}} / 1-\mathrm{u}_{\mathrm{t}}\left[\left(1-\mathrm{u}_{\mathrm{t}} \mathrm{w}_{\mathrm{t}}\right) \delta+\mathrm{e}_{\mathrm{t}}-\left(\mathrm{q}_{\mathrm{t}}-\mathrm{q}_{\mathrm{t}-1}\right) / \mathrm{q}_{\mathrm{t}}\right.
$$

where, $c_{t}$ is the cost of the capital service, $q_{t}$ is the price index for capital goods, $u_{t}$ is the aliquot part of the tax; $\mathrm{w}_{\mathrm{t}}$, part of the reducing depreciation of taxable result, $\delta$ is the depreciation rate; $\mathrm{e}_{\mathrm{t}}$ is the cost of the capital measured by the real interest rate. However, given the trend toward equalization of interest rates, the cost of the alternative is simplified as:

$$
r_{\text {br r } \$}=\left[\left(i_{\text {eua }}+\text { risco }\right)\right]\left(e_{t-1} / e_{t}\right)-\pi
$$

where, $\mathrm{r}_{\mathrm{brr}}$ is the rate of real domestic interest in national currency, $\mathrm{i}_{\text {eua }}$ the interest rate of the reserve currency, $e_{t-1}$ the future exchange rate, $e_{t}$ the current exchange rate and $\pi$ the price index.

Accordingly, a devaluation of the local currency reduces the real interest rate and the cost of capital.

It should be observed that the approach using the production function implies choosing between the use of the capital and the use of labor, depending on their relative prices. Thus, the choice of production is not necessarily associated with an investment choice. The association between the fluctuations in the level of product and stock of desired capital implies a production function with fixed coefficients. Thus, the increase in production induces productive inversions and raises the level of employment of labor. As a result, a consistent variation in the level of activity that gives rise to a degree of occupation of the existing production capacity such as to eliminate the idleness of productive plants will necessarily imply the increase in both production inputs considered in the production function: capital and labor.

If it is assumed that a production function with fixed coefficients, the average cost of the worker becomes a determinant of investment choices because, instead of a substitution of the input labor for the input capital, there will be a decrease in both. Possibly, there will be a displacement from the labor force to jobs in less competitive sectors, with unmarketable products.

It should be noted that this paper is not here despising the offer price behavior of capital goods. But considering an open economy with free flow of goods, the law of one price guarantees the trend of convergence of prices in the tradable goods sector, among which is the segment of machinery and equipment. The same does not apply to labor force, since the flow of workers has less mobility when compared to the flow of goods. Thus, it is considered that the average labor costs tend to inhibit expenditures of capital goods and are more relevant to the choice.

In Jorgenson's model, there is no component explicitly associated with the profitability. There is, however, in replacement or proxy, the effect of the product range on the stock of desired capital stock or optimal capital stock. 
What is proposed instead, is to make explicit in the equation the expectations of future profit increasing the accelerator effect.

Thus, not only the variation in activity level would impact on the optimal capital stock. Access to this variation in the income plays a fundamental role on the expectations.

Therefore, the effect of exchange rate on both the reduction of exports as well as in the increase in imports is an indicator of the degree of "access" that domestic companies have on household consumption internally and the level of access to the share of world income.

The Thirlwall's law relates the growth rate of the economy to the ratio of the income elasticity of imports and income elasticities of exports.

$$
\mathrm{I}=\theta\left(\mathrm{Y}_{\mathrm{t}+1}-\mathrm{Y}_{\mathrm{t}}\right)
$$

where, $\mathrm{I}$ is investment, $\theta$ is simple accelerator effect, $\left(\mathrm{Y}_{\mathrm{t}+1}-\mathrm{Y}_{\mathrm{t}}\right)$ the change in activity level.

In the flexible accelerator model, an effect with time lags and decreasing weights is used.

We'll think of the throttle model in two stages. In the first one, we'll "ponder" the access to variation in the level of activity (XVIII) and then consider the time lags of the flexible accelerator model.

$$
\mathrm{I}=\theta\left[\epsilon_{\mathrm{x}}^{\mathrm{R}} / €_{\mathrm{m}}^{\mathrm{R}}\left(\mathrm{Y}_{\mathrm{t}+1}-\mathrm{Y}_{\mathrm{t}}\right)\right]
$$

In this way, the optimal capital stock moves whenever there is economic growth and, analogously, when there is growth of the income elasticity of exports, increasing access to the international market. However, the growth of the income elasticity of imports minimizes or reduces the impact of variation in the level of activity on the desirable stock of capital, discouraging productive investments.

So, it is not associating investment with the exchange elasticities of exports and imports, but relating the profit expectation to the income elasticity and the cost of the service of capital to the exchange rate.

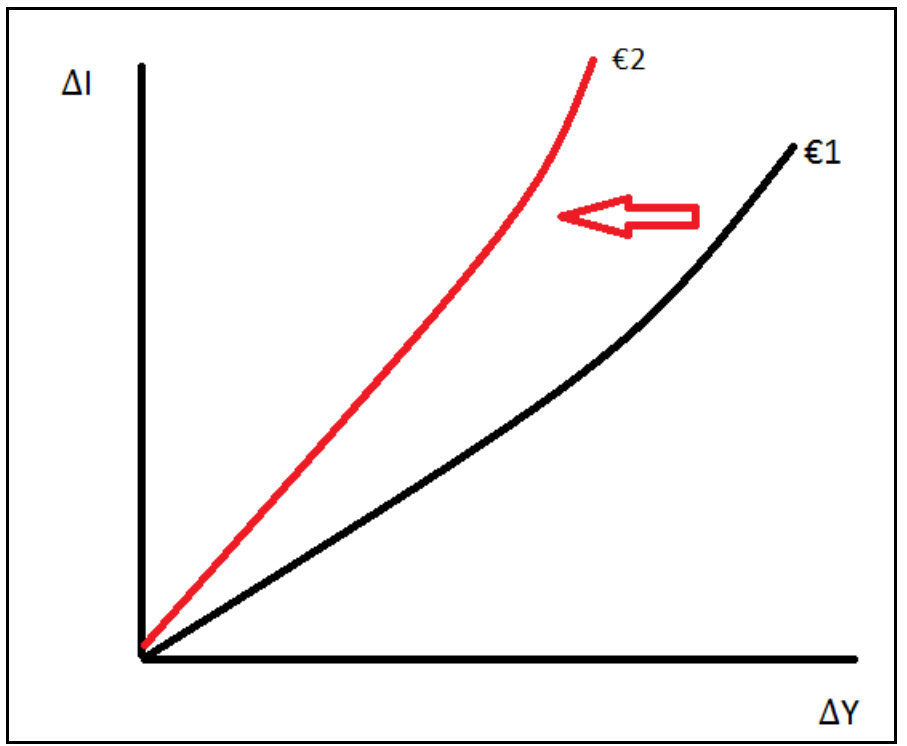

Figure 1. Reduction on income elasticity of investments. Source: Author's elaboration.

The curve changes slope and shifts to the left when the ratio of the income elasticity of exports and the income elasticity of imports increases $\left(€^{\mathrm{R}} \times \epsilon_{\mathrm{X}}^{\mathrm{R}}{ }_{\mathrm{M}}\right)$, in this case, a small variation in activity level promotes an increase in the stock of optimal capital and an expressive shift in investment spending. 


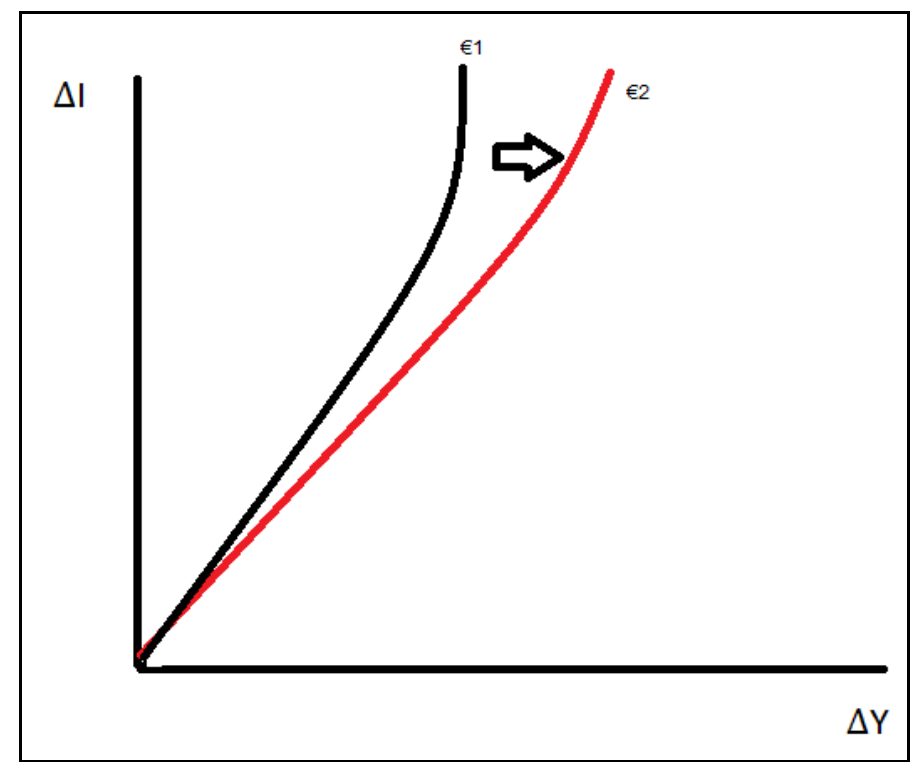

Figure 2. Increase on income elasticity of investments. Source: Author's elaboration.

The curve changes the slope and shifts to the right when the ratio of the income elasticity of exports and the income elasticity of imports decreases $\left(€^{R} \times / €^{R}\right.$ $)$, in this case an increase in income promotes lower impacts on the stock of desired capital as well as on the investment.

Figures 1 and 2 show how the inclination, or the impact of income variation on investment, is changed when the ratio of the income elasticity of exports and the income elasticity of imports increases and decreases respectively. The Thirlwall coefficient starts to enhance or slow down the impact of variation in the level of activity on productive investments.

However, the intuition is that the curve is not a linear function, but a curve, in such a way as there is an inflection point from which the investments cease and start to decrease. Even a negative variation is possible in case the depreciation is greater than the actual investment.

\section{Conclusions}

The investment functions that are enshrined in the literature do not include the exchange rate or its oscillation as a relevant variable to explain the choice of investment. The regarded relation between these variables is negative, assuming that a reduction in the exchange rate stimulates spending productive investment on account of cheapening the access to more sophisticated machinery and equipment in the international market.

This paper aimed to relate the productive investment choices in a production function with fixed coefficients, with the comparative index of the average cost of labor and the exchange rate. It is considered that the fluctuation of the exchange rate can constitute an important measure of risk and that its significant variation can paralyze investment decisions that are not related to specific market needs. Thus, a wide variation in exchange rate was considered as a dummy variable that takes zero and therefore, the measurement of the effect of the exchange rate level on investment is negligible.

Additionally, the ratio between the household income elasticity of imports and income elasticity of world export was considered as a measurement of the magnitude of the effect of the exchange rate on investment choices in fixed capital additionally. 
It now remains for other work, testing the investment function and seeing to what extent this model can explain the performance of productive investments in recent years and even help predict the behavior of productive investments.

\section{References}

ALVES, Joana Duarte Ouro et al. (2007). Evolution of investment theory and empirical analysis for Brazil. National Meeting of Economy. ANPEC. Access: http://www. anpec. org. br/encontro2007/artigos/A07A172. pdf. Acesso em, v. 12, 2007.

BRESSER-PEREIRA, L. C. (1991). Accumulation of capital, profits and interest. São Paulo: Fundação Getúlio Vargas, Departamento de Economia, Working Paper, n. 3.

BRESSER PEREIRA, L. C. (2010). Exchange rate, Dutch disease, and industrialization. Cadernos FGV Projetos, 5(14), 68-73.

BRESSER-PEREIRA, L. C. (2012). The exchange rate at the center of development theory. Estudos avançados, 26(75), 7-28.

BRESSER-PEREIRA, L. C. (2013). The value of Exchange rate and Dutch Disease. Brazilian Journal of Political Economy, 33(132), 371-387.

CARVALHO, L. F., \& VIEIRA, F. V. (2015). Taxa Exchange rate and stock price: Evidence for Brazil. Revista de Finanças Aplicadas, 4, 1-48.

JORGENSON, M. G. M., \& RODRIGUES J. W. (1998). Determinants of private investment in Brazil: 1970-1995.

MELLO, Cristina Helena Pinto de. (1993). Elasticity-interest of the investment demand: A comparative historical analysis. EAESP-FGV.

MELLO, Cristina Helena Pinto de. (2000). Condicionantes Conditional prices of capital goods in the 1980s.EAESP-FGV.

MYERS, S. C., \& MAJLUF, N. S. (1984). Corporate financing and investment decisions when firms have information that investors do not have. Journal of financial economics, 13(2), 187-221.

RAMA, M. (1993). Empirical investment equations for developing countries. Striving for growth after adjustment: The role of capital formation, 107-143.

RONCI, M. V. (1988). A note on the specification of the aggregate investment function for developing countries. Revista Brasileira de Economia, 42(2), 179-194.

SERVEN, L., \& SOLIMANO, A. (Ed.). (1993). Striving for growth after adjustment: the role of capital formation. World Bank Publications. 